\title{
Modeling district level economic disparities across Uttarakhand, India
}

\author{
Dr Shalini Gupta \\ (Assistant Professor, Department of Economics, School of Social Sciences, Doon University, Dehradun, \\ Uttarakhand, 248001, India)
}

\begin{abstract}
Economic development in Uttarakhand, a state in India has accelerated in the last decade however; the progress is largely confined to the plains. The study attempts to analyze district level economic disparities in Uttarakhand. The six key economic development variables namely, per capita income, infrastructure, health, education, industrial employment and tourism have been examined and modeled in the study. The districts have been ranked in their respective order of economic development using the weights derived through the pairwise comparison of the identified development variables. There is no evidence of decline in regional disparities across the hill and plain districts. The economic growth has become more polarized in the plains. Interestingly, four out of the six districts of Kumaon division have emerged as economically the most backward districts. The study concludes with policy implications.
\end{abstract}

Keywords: Economic disparities, Inclusive development, Pair-wise comparison, Uttarakhand

\section{Introduction}

The political dynamics of the world's largest democracy has compelled inclusive-development to be a key agenda for governance. This was also emphasized by the Honorable Chief Minister of Gujarat Sh. Narendra Modi in his informal conversations with his countrymen in the evening of February $12^{\text {th. }}$, 2014. This is of specific relevance for the state of Uttarakhand because this primarily hilly state was born out of the demand of its people to minimize disparities that were otherwise prevailing in the erstwhile Uttar Pradesh (UP) of which the state was a part. The criticality of evaluating economic disparities periodically cannot be ignored for Uttarakhand as it is feared that the newly born state may move into the same social turmoil, which was the cause for its creation on $9^{\text {th. }}$ November, 2000.

The economic disparities do accelerate for a state aiming to boost its growth rate [1]. Uttarakhand grew at $3.5 \%$ before attaining statehood. This jumped to $11 \%$ after its formation [2], which indicates a strong possibility of the state moving into a pattern of skewed growth across its districts. This is particularly relevant as large parts of its area are still devoid of features that are essential for balanced and inclusive economic development.

Several agencies, e.g., World Bank (http://data.worldbank.org), United Nations Development Program (UNDP), etc. have defined, established and published data of economic development indicators of different countries, while Government of India and the Government of Uttarakhand have published some district level data for the state of Uttarakhand. Review of some literature was done to understand the complex process of economic disparities at the district level of the state under consideration. It was highlighted in a study that skewed growth of manufacturing and, therefore, industrial employment across districts causes economic disparities [3]. The economic liberalization witnessed by India may also cause disparities as it was sensitive to levels of attainment used [4]. In a study carried out on poverty, it was found that though the overall level of poverty has declined, yet distribution of poverty across districts had significant variance [5].

Researchers have used several techniques to rank the districts according to prevailing economic disparities. TOPSIS (Technique for Order Preference by Similarity to Ideal Solution) and Shannon entropy were used to rank the regions across Malaysia [6]. In another study, the regional disparities were evaluated by analyzing the household consumption data across regions using analysis of variance of logarithms [7]. The methods of spatial auto correlation and spatial heterogeneity were used to study the clusters of high and low per capita GDP and these were linked to regional development [8]. In this paper an attempt has been made to rank the districts in order of economic development using the weights derived through the paired-comparison between the variables that signify the district level disparities. This will enable the planners and people in governance to take critical developmental decisions.

The paper is divided into six Sections. Section 2 gives the demographic profile of the state of Uttarakhand. Section 3 describes the variables influencing district level economic disparities in Uttarakhand. Section 4 details the disparities modeling by use of pairwise comparison of the variables to model and evaluate 
the relative weights of the variables. Section 5 infers on the regional disparities and finally the last section 6 concludes.

\section{Demographic profile of Uttarakhand}

Uttarakhand emerged as the $27^{\text {th. }}$ state of India on $9^{\text {th. }}$ November 2000 after a prolonged struggle, which took roots in the year 1930, leading to the fulfillment of the long cherished dream of the people of this hilly region. Uttarakhand is the ancient term for the central stretch of the Indian Himalayas.

As per census of 2011, the state of Uttarakhand has a population of approximately 10,086,292 and is spread over 53,483 sq. Km. The average population density is 189 per sq. km. District Dehradun records the highest literacy of 84.25 . The state has primarily an agrarian economy with more than $75 \%$ of the population depending on it. The decadal growth of population during the period 2001-11 was $19.17 \%$ as against the national average of $17.64 \%$. The state has two divisions namely, Garhwal and Kumaon, which are further divided into thirteen districts as shown in Figure 1. The districts falling in Garhwal division are Dehradun, Haridwar, Chamoli, Rudraprayag, Tehri Garhwal, Uttarkashi, and Pauri Garhwal. These districts have some of the highest Himalayan peaks located here. The districts, which are a part of Kumaon division, are Almora, Nainital, Pithoragarh, Udham Singh Nagar, Bageshwar, and Champawat. Table 1 enumerates district-level data for the state of Uttarakhand. It is relevant to note that hill districts of Uttarakhand have been riddled with lack of infrastructure, employment and income generating opportunities [9].

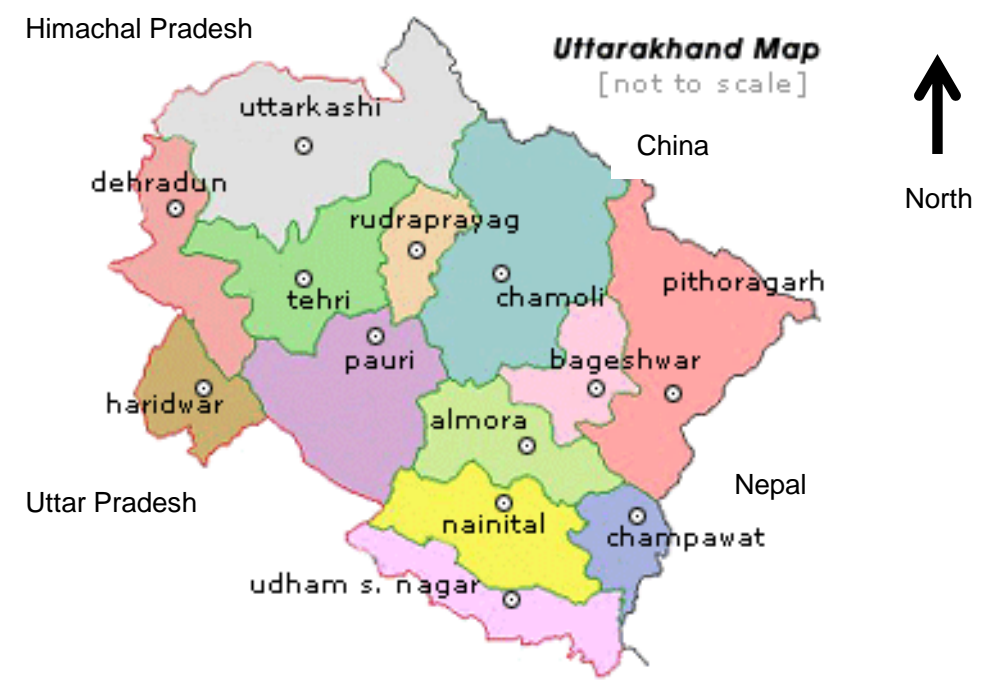

Figure 1: Map of Uttarakhand

Table 1: Census 2011 data for Uttarakhand

\begin{tabular}{|c|c|c|c|c|c|c|c|}
\hline S. No. & District & Area & Population & $\begin{array}{l}\text { Population } \\
\text { Growth } \\
\text { Rate }\end{array}$ & $\begin{array}{l}\text { Sex } \\
\text { Ratio }\end{array}$ & Literacy & $\begin{array}{l}\text { Population } \\
\text { Density }\end{array}$ \\
\hline \multicolumn{8}{|c|}{ sq. km. } \\
\hline 1 & Haridwar & 2360 & $1,890,422$ & $30.63 \%$ & 880 & $73.43 \%$ & 801 \\
\hline 2 & Dehradun & 3088 & $1,696,694$ & $32.33 \%$ & 902 & $84.25 \%$ & 549 \\
\hline 3 & $\begin{array}{l}\text { Udham Singh } \\
\text { Nagar }\end{array}$ & 3055 & $1,648,902$ & $33.45 \%$ & 920 & $73.10 \%$ & 649 \\
\hline 4 & Nainital & 3422 & 954,605 & $25.13 \%$ & 934 & $83.88 \%$ & 225 \\
\hline 5 & Pauri Garhwal & 5320 & 687,271 & $-1.41 \%$ & 1103 & $82.02 \%$ & 129 \\
\hline 6 & Almora & 3689 & 622,506 & $-1.28 \%$ & 1139 & $80.47 \%$ & 198 \\
\hline 7 & Tehri Garhwal & 3796 & 618,931 & $2.35 \%$ & 1077 & $76.36 \%$ & 170 \\
\hline 8 & Pithoragarh & 7169 & 483,439 & $4.58 \%$ & 1020 & $82.25 \%$ & 68 \\
\hline 9 & Chamoli & 7520 & 391,605 & $5.74 \%$ & 1019 & $82.65 \%$ & 49 \\
\hline
\end{tabular}


District level economic disparities across Uttarakhand, India

\begin{tabular}{rlllllll}
\hline 10 & Uttarkashi & 8016 & 330,086 & $11.89 \%$ & 958 & $75.81 \%$ & 41 \\
11 & Bageshwar & 1696 & 259,898 & $4.18 \%$ & 1090 & $80.01 \%$ & 116 \\
12 & Champawat & 2004 & 259,648 & $15.63 \%$ & 980 & $79.83 \%$ & 147 \\
13 & Rudraprayag & 2439 & 242,285 & $6.53 \%$ & 1114 & $81.30 \%$ & 122 \\
\hline
\end{tabular}

III. Variables influencing district-level economic disparities

The disparities across the districts of Uttarakhand are quantified based on a few relevant development indicators. These are broadly classified as: per capita income, the infrastructure, health, education, employment and tourism. The development variables and their sub-variables are shown in Table 2. These variables are elaborated and discussed further for their proper understanding, appreciation and quantification. Each development variable is defined in terms of its sub-variables, and quantified by the normalized and weighted value of its sub-variables.

Table 2: Variables considered for evaluating developmental disparities across districts

\begin{tabular}{|c|c|c|}
\hline S.No & Development variables & Sub- variables \\
\hline 1 & Income $-\mathrm{A}$ & - $\quad$ Per capita income \\
\hline 2 & Infrastructure - B & $\begin{array}{l}\text { - } \quad \text { Road length per ' } 000 \text { square } \mathrm{km} \\
\text { - } \quad \% \text { household with electricity connection } \\
\text { - } \quad \% \text { households with water connection inside the dwelling unit } \\
\text { - } \quad \% \text { households with toilet inside the dwelling unit } \\
\text { - } \quad \text { Net irrigated area as a } \% \text { of sown area }\end{array}$ \\
\hline 3 & Health - C & $\begin{array}{l}\text { - Number of government hospitals per } 100,000 \text { population } \\
\text { - } \quad \text { Number of hospital beds per } 100,000 \text { population }\end{array}$ \\
\hline 4 & Education - D & $\begin{array}{ll}\text { - } & \text { Literacy rate } \\
\text { - } & \text { Ratio of primary school enrolments to total population } \\
\text { - } & \text { Ratio of upper primary school enrolments to total population } \\
\text { - } & \text { Ratio of vocational training institute enrolments to total population }\end{array}$ \\
\hline 5 & Employment - E & - Industrial employment to work-force ratio \\
\hline 6 & Tourism $-\mathrm{F}$ & - Domestic and Foreign tourist arrivals \\
\hline
\end{tabular}

\subsection{Income (A)}

Per capita income is a strong indicator of development across the districts. The district level raw data for this variable has been sourced from Uttarakhand annual report for 2011-12 presented during the discussions with Hon. Chief Minister, UK and Deputy Chairman, Planning Commission, Government of India. Column 3 of Table 3 shows the normalized value of per capita income for different districts of the state.

\subsection{Infrastructure $(B)$}

Good infrastructure in a region is essential for reducing the disparities. It is the responsibility of the state to create infrastructure and it does this from its own funds. Creation of infrastructure is dependent on the governance decisions. The quantification of this variable has been done on the basis of five sub-variables, which have been assigned equal weightage of 0.20 . These are length of "pucca roads" [a local term used to describe roads made of stone, cement, mortar, tar-coal, etc.] in kms per thousand sq. km; percent of households with electricity connection, drinking water and toilet inside the dwelling and net irrigated area as percentage of sown area. The district level data for these have been sourced from reference [2]. The normalized value of this variable is evaluated and shown in the fourth column of Table 3.

\subsection{Health $(C)$}

Good health of the people is essential for economic development. The number of medical centers and the hospital beds, maternal mortality ratio, infant mortality rate and under-five mortality rate, etc. are accepted indicators for assessing the health standards in a region. However, the maternal mortality ratio, the infant mortality rate and the under-five mortality rate are a result of the health infrastructure. Therefore, in evaluating the disparities across the districts only those parameters, which are initiators of good health, are considered, i.e., the no. of allopathic hospitals, hospitals and primary health centers per 100,000 of population and the no. of available beds in these for every 100,000 population. The raw data for these sub-variables has been sourced 
from district level indicators for health (Source: Statistical diary of districts 2011, Government of Uttarakhand; Annual Health Survey Bulletin 2011-12 for Uttarakhand, Office of the Registrar General and Census Commissioner, India, MHA, Govt. of India, New Delhi, India). Column 5 of Table 3 shows the normalized values of health variable with equal weight.

\subsection{Education (D)}

Education is very important for the development process. Education can significantly increase employment potential and improve the economic prospects. However, it is observed that merely being literate is not sufficient for employment. Therefore, a weightage of 0.10 is assigned to this sub-variable and the weightages have progressively been increased based on education levels that increase employability. The other sub-variables that have been considered to evaluate this variable are per capita enrolments of primary students (weightage $=0.20$ ), per capita enrolments of upper primary students (weightage $=0.35$ ) and per capita enrolments of vocational institute (weightage $=0.35$ ). The data for these sub-variables, has been sourced from the report on "District-wise skill gap study for the state of Uttaranchal - 2017-22" prepared by National Skill Development Corporation. Column 6 of Table 3 shows the normalized value of this variable across the various districts of the state.

\subsection{Employment $(E)$}

Agriculture contributed only 15\% to the Gross State Domestic Product for the year 2010-11 (Source: Uttarakhand 12th five year plan and annual plan report for 2012-13). It is assumed in the current paper that majority of the population is involved in subsistence agriculture and therefore, population engaged in agriculture has not been considered in the analysis. The district wise employment data as of December 2012 from 230 large industries having an investment of INR 274,508.1 million and 41,692 small and medium enterprises having an investment to the tune of INR 79,994.19 million has been sourced from Directorate of Industries, Uttarakhand.

It is observed that the employment in large and small and medium enterprises boosts growth in most of the secondary and tertiary sectors. Hence, the ratio of industrial employment to available work force can be taken as a fair indicator for judging the development disparities among the districts. The data for the available work force in each district is sourced from the report on "District-wise skill gap study for the state of Uttaranchal - 2017-22" prepared by National Skill Development Corporation and the numerical evaluation of the normalized employment variable is given in the seventh column of Table 3.

\subsection{Tourism $(F)$}

Tourism is particularly important for the hill state of Uttarakhand as it is one of the major sources of revenue. The breathtaking views of the Himalayas and the religious beliefs associated with some places of the state (e.g. Badrinath and Kedarnath, Gangotri, Yamunotri, Hemkund Saheb, Haridwar and Rishikesh, etc.) attract large number of domestic and foreign tourists. The annual arrival of domestic and foreign tourists has been sourced from Department of Tourism, Government of Uttarakhand. Column 8 of Table 3 shows the normalized value of this variable across the districts.

Table 3: Evaluated normalized values of development variables

\begin{tabular}{cccccccc}
\hline S.No. & District & Income & Infrastructure & Health & Education & Employment & Tourism \\
\hline & Variables & $\mathrm{A}$ & $\mathrm{B}$ & $\mathrm{C}$ & $\mathrm{D}$ & $\mathrm{E}$ & $\mathrm{F}$ \\
\hline 1 & 2 & 3 & 4 & 5 & 6 & 7 & 8 \\
\hline 1 & Haridwar & $0.4187^{+}$ & 0.4114 & 0.1444 & $0.1489^{-}$ & $0.6131^{+}$ & $0.9400^{+}$ \\
2 & Dehradun & 0.3628 & $0.4244^{+}$ & $0.3989^{+}$ & 0.2119 & 0.2698 & 0.2294 \\
3 & $\begin{array}{c}\text { Udham Singh } \\
\text { Nagar }\end{array}$ & 0.2819 & 0.4081 & $0.0789^{-}$ & 0.1957 & 0.5079 & 0.0076 \\
4 & Nainital & 0.3433 & 0.3943 & 0.3700 & 0.3030 & 0.1697 & 0.0770 \\
5 & Pauri Garhwal & 0.2346 & 0.2130 & 0.1779 & 0.2572 & 0.1992 & 0.0488 \\
6 & Almora & 0.2409 & 0.1751 & 0.3327 & $0.3544^{+}$ & 0.1066 & 0.0113 \\
7 & Tehri Garhwal & 0.2834 & 0.1875 & 0.2491 & 0.2599 & 0.1464 & 0.0604 \\
8 & Pithoragarh & 0.2384 & 0.1490 & 0.3129 & 0.2877 & 0.1084 & 0.0121 \\
\hline
\end{tabular}


District level economic disparities across Uttarakhand, India

\begin{tabular}{cccccccc}
\hline 9 & Chamoli & 0.2671 & $0.1432^{-}$ & 0.2543 & 0.2987 & 0.1301 & 0.1971 \\
10 & Uttarkashi & 0.2116 & 0.1655 & 0.2593 & 0.2389 & 0.1829 & 0.0835 \\
11 & Bageshwar & $0.1893^{-}$ & 0.1450 & 0.2338 & 0.2644 & 0.0890 & $0.0048^{-}$ \\
12 & Champawat & 0.2282 & 0.1608 & 0.1833 & 0.3475 & $0.0849^{-}$ & 0.0050 \\
13 & Rudraprayag & 0.2040 & 0.1458 & 0.3466 & 0.2586 & 0.1312 & 0.0746 \\
+ District having the highest value of the variable & & & & \\
- District having the lowest value of the variable
\end{tabular}

The dimensionless normalized values of all the variables have been evaluated and tabulated in Table 3 for further analysis of district level disparities.

\section{Disparities Modeling}

Table 3 shows the evaluated and normalized values of all the variables, i.e., A, B, ..., F, which are considered for evaluation of the development disparities. In order to rank the districts, the weightage of each variable should be determined. Pair-wise comparison of the variables can help in this. In this method pair wise comparison is made between the two variables say, $\mathrm{X}$ and $\mathrm{Y}$. The scoring scheme for the comparison is shown in Table 4.

Table 4: Scoring scheme in pairwise comparisons

\begin{tabular}{cc}
\hline \multicolumn{1}{c}{ Comparison } & Score \\
\hline If the variable X scores over variable Y in a major way & X 3 \\
If the variable Y scores over variable X in a major way & Y 3 \\
If the variable X scores over variable Y in a medium way & X 2 \\
If the variable Y scores over variable X in a medium way & Y 2 \\
If the variable X scores over variable Y in a minor way & X 1 \\
If the variable Y scores over variable X in a minor way & Y1 \\
\hline
\end{tabular}

Now, each variable is compared pair wise and for each pair, a weight is determined as per the scheme of scoring given in Table 4. Table 5 shows the relative score for each variable. The score in the table is obtained for all values of scores for variables $\mathrm{A}, \mathrm{B}, \mathrm{C}, \ldots, \mathrm{F}$. The weight for each variable is obtained by dividing the variable score by the total score. It is, however, important to realize that these relationships among variables, needs to be determined by a team of experts.

Table 5: Relative score of each variable using pairwise comparison of variables

A

\begin{tabular}{|c|c|c|c|c|c|c|c|}
\hline B & $\mathrm{C}$ & D & $\mathbf{E}$ & $\mathbf{F}$ & Score & Weight of variable & \\
\hline A 1 & A 3 & A 2 & A 1 & A 1 & 8 & 0.2963 & Income \\
\hline \multirow[t]{6}{*}{ B } & B 3 & D 1 & E 1 & B 1 & 4 & 0.1481 & Infrastructure \\
\hline & \multirow[t]{5}{*}{ C } & C 1 & E3 & F 3 & 1 & 0.0370 & Health \\
\hline & & \multirow[t]{4}{*}{ D } & E 3 & F 2 & 1 & 0.0370 & Education \\
\hline & & & \multirow[t]{3}{*}{$\mathbf{E}$} & F 1 & 7 & 0.2593 & Industrial Employment \\
\hline & & & & $\mathbf{F}$ & 6 & 0.2222 & Tourism \\
\hline & & & & Total & $=27$ & & \\
\hline
\end{tabular}

The next step is to convert the values of the development variables given in Table 3 on a scale of 0 100 , by multiplying entries in each cell by 100 . The weighted development score, which is the weighted sum of all the variables for each district is shown in the ninth column and the assessed development rank of each district is shown in 9th and last column of Table 6.

Table 6: Development score and rank of districts of Uttarakhand

\begin{tabular}{|c|c|c|c|c|c|c|c|c|c|}
\hline S.No. & District & Income & Infrastructure & Health & Education & Employment & Tourism & $\begin{array}{c}\text { District } \\
\text { develop- } \\
\text { ment score }\end{array}$ & $\begin{array}{c}\text { Develop- } \\
\text { ment } \\
\text { Rank }\end{array}$ \\
\hline & Variables & A & B & $\mathrm{C}$ & D & $\mathrm{E}$ & $\mathrm{F}$ & & \\
\hline & $\begin{array}{l}\text { Weightage of } \\
\text { variables }\end{array}$ & 0.2963 & 0.1481 & 0.0370 & 0.0370 & 0.2593 & 0.2222 & & \\
\hline 1 & Haridwar & $41.87^{+}$ & 41.14 & 14.44 & $14.89-$ & $61.31^{+}$ & $94.00^{+}$ & 56.37 & I \\
\hline 2 & Dehradun & 36.28 & $42.44^{+}$ & $39.89^{+}$ & 21.19 & 26.98 & 22.94 & 31.39 & II \\
\hline
\end{tabular}


District level economic disparities across Uttarakhand, India

\begin{tabular}{|c|c|c|c|c|c|c|c|c|c|}
\hline 3 & $\begin{array}{c}\text { Udham Singh } \\
\text { Nagar }\end{array}$ & 28.19 & 40.81 & $7.89^{-}$ & 19.57 & 50.79 & 0.76 & 28.75 & III \\
\hline 4 & Nainital & 34.33 & 39.43 & 37.00 & 30.30 & 16.97 & 7.70 & 24.62 & IV \\
\hline 5 & $\begin{array}{c}\text { Pauri } \\
\text { Garhwal }\end{array}$ & 23.46 & 21.30 & 17.79 & 25.72 & 19.92 & 4.88 & 17.97 & VII \\
\hline 6 & Almora & 24.09 & 17.51 & 33.27 & $35.44^{+}$ & 10.66 & 1.13 & 15.29 & $\mathbf{X}$ \\
\hline 7 & $\begin{array}{c}\text { Tehri } \\
\text { Garhwal }\end{array}$ & 28.34 & 18.75 & 24.91 & 25.99 & 14.64 & 6.04 & 18.19 & VI \\
\hline 8 & Pithoragarh & 23.84 & 14.90 & 31.29 & 28.77 & 10.84 & 0.121 & 14.57 & XI \\
\hline 9 & Chamoli & 26.71 & $14.32^{-}$ & 25.43 & 29.87 & 13.01 & 19.71 & 19.84 & $\mathbf{V}$ \\
\hline 10 & Uttarkashi & 21.16 & 16.55 & 25.93 & 23.89 & 18.29 & 8.35 & 17.16 & VIII \\
\hline 11 & Bageshwar & $18.93^{-}$ & 14.50 & 23.38 & 26.44 & 8.90 & $0.48^{-}$ & 12.02 & XIII \\
\hline 12 & Champawat & 22.82 & 16.08 & 18.33 & 34.75 & $8.49^{-}$ & 0.50 & 13.42 & XII \\
\hline 13 & Rudraprayag & 20.40 & 14.58 & 34.66 & 25.86 & 13.12 & 7.46 & 15.50 & IX \\
\hline
\end{tabular}

\section{Inferences}

Development disparity between the thirteen districts has been evaluated by numerical evaluation of the district development score shown in column 9 of Table 6. It is observed that the growth is heavily biased towards the districts whose major parts are located in the plains while the districts in the hills continue to languish. Table 6 shows that the development is skewed towards only the four districts of Haridwar, Dehradun, Udham Singh Nagar and Nainital, while the four districts of Almora, Pithoragarh, Champawat and Bageshwar, all in Kumaon region, are way behind in development. It is further observed that Haridwar with a score of 56.37 is way ahead of the second ranked district Dehradun. This is comparable to the study conducted by the Planning Commission, Government of India, which inferred that Tehri Garhwal, Champawat and Chamoli districts of Uttarakhand to be low on development, while Haridwar, Dehradun and Udham Singh Nagar were ranked high. This inference of Planning Commission, Govt. of India was based on twenty four development indicators.

A closer look at Table 6 shows that Bageshwar scores the poorest on per-capita income and tourism, Chamoli scores lowest on infrastructure, Udham Singh Nagar on health, Haridwar on education and Champawat on employment. However, overall consideration of all the six variables gives the overall development status of the thirteen districts and their relative rank, which is shown in last column of Table 6.

\section{Conclusions}

This paper deals with district level development disparities in the state of Uttarakhand in India. It models and evaluates the regional disparities based on paired comparison approach that is easy to implement. The methodology helps in identifying the weak districts from economic development perspective. It also provides a direction for allocation of development funds to ensure inclusive development. It may help in deciphering the development dynamics across the various districts of Uttarakhand and will facilitate mid-course correction and avoid the development process moving into a divergent loop and prevent social discontentment in future.

\section{Acknowledgements}

The author is thankful to officials in the different departments of the Government of Uttarakhand, India for providing data to carry out this work. The author is also indebted to Prof. V. K. Jain, Vice-Chancellor, Doon University for his constant motivation to undertake this work.

\section{References}

[1] Fan, C. C. (1997). Uneven development and beyond: regional development theory in post-Mao China. International Journal of Urban and Regional Research 21.4, 620-39.

[2] Kar, S. (2007) Inclusive Growth in Hilly Regions: Priorities for the Uttarakhand Economy. Institute of Economic Growth Working Paper, E/281/2007, New-Delhi, India.

[3] Barua A. and Chakraborty, P. (2010) Does Openness Affect Regional Inequality? A Case Study for India. Review of Development Economics 14.3, 447-65. 
[4] Singh, N., Bhandari, L., Chen, A. and Khare, A. (2002) Regional inequality in India: A fresh look. UC Santa Cruz Economics Working Paper, 532, 02-23.

[5] Das, S. K. and Barua, A. (1996). Regional inequalities, economic growth and liberalization: A study of the Indian economy. The Journal of Development Studies 32.3, 364-90

[6] Krimi, M. S., Yusop, Z. and Hook, L. S. (2010). Regional development disparities in Malaysia. Journal of American Science, 6.3, $70-8$.

[7] Bhattacharya, N. and Mahalanobis, B. (1967) Regional disparities in household consumption in India. Journal of the American Statistical Association 62.317, 143-61.

[8] Le Gallo, J. and Ertur, C. (2003) Exploratory spatial data analysis of the distribution of regional per capita GDP in Europe, 19801995. Papers in Regional Science 82.2, 175-201.

[9] Kandari, P. (2013) Migration pattern and the increasing participation of females in the economy of hill rural areas: A study of Pauri district in Uttarakhand. IOSR Journal of Humanities and Social Science, 17(5), 27-33.

http://www.thephonicspage.org/On\%20Phonics/profitable.html (accessed on 19 December 2013).

http://www.census2011.co.in/census/state/districtlist/uttarakhand.html (accessed on 10 December 2013).

http://www.euttaranchal.com/uttaranchal/districts.php (accessed on 10 December 2013).

http://censusindia.gov.in/2011-provresults/ indiaatglance.html (accessed on 1 December 2013).

\section{Biographical sketch}

Shalini Gupta is Assistant Professor of economics at the Department of Economics, School of Social Sciences, Doon Unversity, Dehradun, India. She did her Ph.D. from Jawahar Lal Nehru University, New Delhi, India. She has 17 years of experience and has worked on several international projects of FAO, OECD and ILO. She has published papers in International/ National Journals. Her current areas of interest include regional and economic development and gender economics. 